\title{
Een Nederlandse calvinist in Amerika
}

Postseculiere kritiek in The Blood of the Lamb (1961) van Peter de Vries

Daan Lameijer en Bram Ieven

NEDLET 22 (1): 25-45

DOI: 10.5117/NEDLET2017.1.LAME

\begin{abstract}
A Dutch Calvinist in the United States: Postsecular Critique in The Blood of the Lamb (1961) by Peter de Vries

With The Blood of the Lamb, Peter de Vries has written a novel that can be qualified as a typical Dutch novel about secularization; but the novel is not Dutch. The Blood of the Lamb is written by an American author of Dutch descent. In this article, Lameijer and leven argue that De Vries's way of dealing with religion can be understood as typical of how Dutch culture in the 20th century dealt with the secularisation of society. Reading The Blood of the Lamb from a contemporary, post-secular perspective, leven and Lameijer demonstrate how Peter de Vries's novel can be taken as the starting point for a reflection on Dutch patterns of religion and secular critique.
\end{abstract}

Keywords: postsecular, Dutch migration, secular critique, The Blood of the Lamb

\section{$1 \quad$ Nederlands, maar dan anders}

In The Blood of the Lamb vertelt Peter de Vries het verhaal van Don Wanderhope, een gereformeerd opgevoede schrijver en intellectueel met $\mathrm{Ne}$ derlandse wortels die achtereenvolgens zijn beminde oudere broer, zijn echtgenote, zijn moeder en zijn 11 jaar oude dochter verliest, en daarnaast hulpeloos moet toezien hoe zijn vader langzaam maar zeker wegzakt in een mix van melancholie en hypochondrie. In het arme maar trotse gezin waarin Don Wanderhope opgroeit, zijn de huiselijke theologische discussies, Bijbelse doemscenario's en religieuze vingerwijzingen niet van de lucht. Maar ondanks dit alles functioneert de familie Wanderhope bepaald 
niet als rolmodel binnen de streng gereformeerde gemeenschap van Nederlandse migranten die sinds het laatste kwart van de negentiende eeuw neerstreken in de buitenwijken van Chicago. ${ }^{1}$ Zo is er bijvoorbeeld de weerspannige oudere broer van Don, Louie, die in een discussie met zijn oom en vader het Bijbelboek Job 'slap' noemt in vergelijking met de tragedies van Aeschylus. Op zijn sterfbed doet Louie zelfs expliciet afstand van het christelijke geloof. Maar ook de vader van Don, Ben, is niet onbesproken binnen de kerkgemeenschap. Hij heeft de reputatie een twijfelaar te zijn, een reputatie die hij mede te danken heeft aan zijn bourgondische instelling - een goed glas whisky, bijvoorbeeld, laat hij niet snel staan. Voor de strenggelovige, Bijbelvaste gemeenschap waarin de Wanderhopes thuishoren behoort een christen echter in de wereld, niet van de wereld te zijn. De moeder van Don heeft er dan ook een hele klus aan om het gezin op het rechte pad te houden en het aanzien binnen de religieuze gemeenschap te handhaven.

Het gezin Wanderhope mag dan geen voorbeeldgezin zijn binnen de gemeenschap van Nederlandse immigranten in Chicago, de samenstelling van het gezin weerspiegelt op ironische wijze de relationele strubbelingen die zich binnen een dergelijke gemeenschap en in dergelijke gezinnen afspelen. Ieder gezinslid vertegenwoordigt een rol die we bijna klassiek kunnen noemen: de opstandige adolescent die zijn geloof verliest, de goedwillige maar niet al te gedisciplineerde vader die naarmate hij ouder wordt steeds lastiger wordt, de oprecht gelovige moeder die lijdt onder het opstandige gedrag van haar zoon en onder het weinig voorbeeldige gedrag van haar echtgenoot. Het enige personage dat niet aan deze typecasting ten prooi valt, is Don zelf.

Na de dood van zijn oudere broer Louie onttrekt Don zich steeds meer aan de huiselijke begrenzing. Hij proeft van het aardse leven en voelt zich vrij in de ontkerkelijkte maatschappij van het grootstedelijke Amerika van de eerste helft van de twintigste eeuw. Wanneer hij op jonge leeftijd op het punt staat zich met zijn vriendin Rena te vestigen in een development - een eerste teken van de uitgestrekte suburbs die het naoorlogse Amerika zouden kenmerken - valt hij ten prooi aan een zenuwinzinking en aan tbc. Het geloof blijkt zijn redding te zijn. Alleen, niet in innerlijke maar in praktische zin: hij wordt opgenomen in een sanatorium, gesponsord door de kerk waar hij in principe nog steeds toe behoort. Deze gebeurtenis is de eerste in een reeks die Don ertoe moeten brengen om voor zichzelf duidelijk te krijgen in hoeverre zijn religieuze achtergrond en zijn relatie tot de religieuze gemeenschap hem vormen en ondersteunen. Maar dat doet hij niet. Integendeel. Don ontleent zijn bestaansrecht aan het feit dat hij zich 
niet expliciet met zijn religieuze achtergrond uiteenzet; hij lijkt zekerheid te putten uit het feit dat hij daartoe niet de noodzaak voelt. Pas wanneer hij zijn dochtertje Carol verliest aan leukemie bereikt hij de beruchte rock bottom en komt hij tot het inzicht dat zijn religieuze vorming en omgeving een beslissende impact hebben op zijn omgang met tegenslag en zijn kijk op het leven.

Bij iedere tegenslag die Don meemaakt in The Blood of the Lamb, staat de moeilijke balans tussen geloof, liefde en lijden in een snel seculariserende maatschappij centraal. Het wedervaren van Don Wanderhope past in dat opzicht vrijwel naadloos in de traditie van de Nederlandse naoorlogse roman over religieuze strubbelingen, zoals Terug naar Oegstgeest (1965) van Jan Wolkers of Een vlucht regenwulpen (1978) van Maarten 't Hart. In The Blood of the Lamb speelt de dood van Don Wanderhopes oudere broer een doorslaggevende rol in zijn verhouding tot het geloof; maar anders dan bij Wolkers balt de protagonist niet zijn vuist richting het geloof, maar spreekt hij bemoedigende, vrijzinnige woorden uit. Net als in het oeuvre van Maarten 't Hart speelt het vooruitzicht van de dood en het verlies van geliefden een grote rol in de manier waarop de hoofdpersoon zich tot zijn geloof verhoudt; maar anders dan bij 't Hart biedt de wetenschap geen soelaas bij het verlies van geloof. Maar bovenal: Peter De Vries is geen Nederlandse schrijver. The Blood of the Lamb is geschreven in het Engels en speelt zich af in een gezin van Nederlandse immigranten in het Noorden van de Verenigde Staten, in de arme South Side van Chicago waar aan het begin van de twintigste eeuw een grote gemeenschap van Nederlandse Amerikanen ontstond. ${ }^{2}$ The Blood of the Lamb mag dan in alle sporen van een Nederlandse culturele en religieuze erfenis dragen, de roman behoort niet tot het corpus van de Nederlandse literatuur of letterkunde in de strikte zin.

Maar juist omdat The Blood of the Lamb geen Nederlandse roman is, kan een analyse waarin we speuren naar de omgang met Nederlandse religieuze patronen een bijdrage zijn aan de vraag wat we verstaan onder Nederlands in een postnationale literatuurbenadering. De analyse van de Nederlandse religieuze thematiek in The Blood of the Lamb staat ons toe om het begrip van 'Nederlandse literatuur' als het ware over de grenzen van de taal heen te trekken: door de thematiek als Nederlands te lezen (waar ook alle aanleiding toe is natuurlijk) wordt het mogelijk om deze thematiek vanuit hele andere ogen te bekijken (die van de overzeese emigrant). ${ }^{3}$ De taal waarin een roman geschreven is, geeft in dit geval niet de doorslag voor de selectie van ons object van analyse, en evenmin neemt de coherente ontwikkeling van een literaire cultuur in een specifieke regio in 
het Noorden van Europa het grootste deel van onze aandacht in beslag. Centraal in onze benadering van het 'Nederlandse' in deze literatuur staat de manier waarop een cultureel-religieuze dynamiek die ontstond in het Nederland van het eind van de negentiende eeuw overgedragen en omgevormd wordt door generaties van migranten in de stedelijke context van Amerika.

Wat ons boeit is het subtiele samenspel van overeenkomst en verschil tussen deze transcontinentale Nederlandse religieuze erfenis in The Blood of the Lamb en de manier waarop eenzelfde thematiek in de Nederlandse literatuur wordt uitgewerkt. De Nederlandse taal, gewoonten en religieuze tradities spelen in The Blood of the Lamb een doorslaggevende rol. Aan het eind van de negentiende eeuw vond een grote migratiegolf plaats naar aanleiding van de kerkscheuring in de Nederlandse Gereformeerde Kerken (1886). Dit leidde onder meer tot een migratiegolf van strenggereformeerde Nederlanders richting Amerika en Canada. In The Blood of the Lamb zijn de ouders van Don een fictief voorbeeld van deze migratiegolf (en, zoals zal blijken, een nogal bijzonder geval). Deze Nederlandse migratiegolf richting Amerika kwam voort uit de religieuze twisten binnen de protestantse gemeenschap, die in Nederland onder meer ook bijdroegen aan het ontstaan van de bijbelgordel. ${ }^{4}$ Nederlandse migranten trokken naar de Verenigde Staten en Canada omdat ze zich niet konden identificeren met de in hun ogen steeds liberaler wordende Nederlandse Hervormde Kerk. In Amerika waren de Nederlandse inwijkelingen lange tijd een groep die zich voornamelijk in de landelijke contreien van Amerika vestigden; ${ }^{5}$ waar echter een stedelijke gemeenschap van emigranten ontstond werden de gemeenschappen gekenmerkt door een zeer gesloten houding. Nederlanders in Amerika hadden hun eigen kerken, hun eigen scholen en hun eigen wijken. De moeilijke - zo niet onmogelijke - balans tussen het behouden van de eigen cultuur (Nederlands en Hervormd), het verwerven van een positie in de nieuwe gemeenschap van Nederlandse immigranten in Amerika, en de onvermijdelijke confrontatie van allerlei mensen en geloofsovertuigingen in een van 's werelds grootste metropolen, bepaalt de vorming en geschiedenis van deze Nederlandse gemeenschap. ${ }^{6}$

Hier ligt meteen ook het belangrijkste onderscheid tussen de Nederlandse romans over secularisering die sinds de Tweede Wereldoorlog verschenen en The Blood of the Lamb. De ontsnapping aan het geloof voor de Nederlandse personages van auteurs zoals Jan Wolkers, Jan Siebelink of Franca Treur hangt samen met het wegtrekken uit kleine, specifieke plaatsen waar de gereformeerde kerk allesbepalend is en waaraan de personages zich als kind of tiener niet of nauwelijks kunnen onttrekken. Het Oegst- 
geest van Wolkers, het Rouveen van Siebelink in Knielen op een bed violen (2008) en de gereformeerde gemeente in Zeeland waar Franca Treurs Dorsvloer vol confetti (2009) zich afspeelt, zijn alle drie onderdeel van de zogenaamde Nederlandse bijbelgordel, een smalle strook die zich uitstrekt van Zeeland tot Friesland en die ook vandaag nog gekenmerkt wordt door haar geslotenheid ten opzichte van de rest van Nederland. ${ }^{7}$ Het milieu van Wolkers, Treur en Siebelink wordt dus geografisch en sociaal bepaald door de bijbelgordel en de gesloten houding die ze aanneemt tot de rest van Nederland. De Nederlandse gemeenschap in de South Side van Chicago waar The Blood of the Lamb zich afspeelt is het resultaat van hetzelfde kerkelijke schisma. Maar in tegenstelling tot Wolkers, Treur en Siebelink, bevinden de Wanderhopes zich van meet af aan in een metropool waarin contact met andere levensstijlen, milieus en etnische groepen - ondanks de afgeschermde aard van de Nederlandse religieuze gemeenschap in Chicago - onvermijdelijk blijkt. ${ }^{8}$ Net als in de bijbelgordel hebben we te maken met twee vrij particuliere vormen van gemeentevorming: in de bijbelgordel zowel als in de stedelijke en mondiale buitenwijken van Chicago werd een poging ondernomen om een relatief geïsoleerde gemeenschap op te zetten. Het is de alledaagse context die anders is: de metropool Chicago die aan het begin van de twintigste eeuw al alle kenmerken van globalisering vertoonde versus de bijbelgordel die relatief landelijk gelegen is en zich lange tijd aan die globalisering wist te onttrekken.

Wanneer we kijken naar de religieuze bespiegelingen die centraal staan in The Blood of the Lamb en de religieuze bespiegelingen in de Nederlandse na-oorlogse seculariseringsromans van Wolkers, 't Hart of Treur, dan valt dus op dat de Nederlandse emigratie en het religieuze, geïsoleerde dorpsleven in de gereformeerde gemeenten niet enkel een gemeenschappelijke origine hebben maar ook leidden tot gelijkaardige sociale interactiepatronen en tot gelijkaardige literaire reflecties. Het spanningsveld tussen streng calvinisme enerzijds en atheïstische afzwering van het religieuze verleden anderzijds, is daarbij zelden zo scherp neergezet als in The Blood of the Lamb. In zijn nawoord bij de Nederlandse vertaling van The Blood of the Lamb merkt Willem-Jan Otten dan ook op dat Het lam dé Nederlandse roman bij uitstek is en dat die ons opluchting en richting verschaft in een tijd vol quasifilosofisch, pseudo-diepzinnig gewauwel over het Iets. Maar waar komt die opluchting vandaan en waarom noemt Otten dit boek een tegenwicht voor het 'vaak zeverig en ietsistisch religieus gerevival'?

Toch is deze al te Nederlandse (maar in Nederland weinig bekende) Amerikaanse roman in een opzicht erg verschillend van de meeste Nederlandse romans met hetzelfde onderwerp. In tegenstelling tot vele seculari- 
seringsromans uit het Nederlandse taalgebied, is The Blood of the Lamb geen compromisloos afscheid van de religie, maar veeleer een reflectie op de onmogelijkheid om aan de religie en al haar denkstructuren eens en voor altijd te ontsnappen. De roman maakt duidelijk dat religie niet enkel een geloofskwestie is, maar ook een cultureel patroon dat zelfs na het seculariseren van het maatschappelijke forum een enorme impact heeft op de wijze waarop de maatschappij en het persoonlijke leven begrepen en benaderd worden. Het gaat hier in feite om een roman die een gelijkaardige thematiek als vele Nederlandse romans behandelt, maar deze thematiek uitwerkt op een manier die we vandaag als postseculier begrijpen: niet het afwerpen van het geloof als zodanig vormt de centrale gebeurtenis die het personage dient door te maken, maar een afrekening met het inzicht dat de religieuze erfenis niet uit te wissen valt.

Dat deze Amerikaanse roman uit 1961 zich vanuit onze eigen theoretische en culturele situatie zo makkelijk als postseculier laat lezen is opmerkelijk, maar valt op zijn minst deels te verklaren door de stedelijke metropool waarin de Nederlandse gemeenschap van Don Wanderhope zich moet positioneren - een realiteit die zich in Nederland pas echt vanaf de jaren zestig van de vorige eeuw enigszins begon af tekenen en die in de zogenaamde bijbelgordel lange tijd geen rol speelde. In de woorden van Edward Said zouden we over The Blood of the Lamb kunnen spreken als een vorm van secular criticism. Het is er Said daarbij om te doen dat een culturele organisatie steeds bestaat uit 'a set of structures inherited from the past, secularized, redisposed, and re-formed by such disciplines as philology, which in turn were naturalized, modernized, and laicized substitutes for (or versions of) Christian supernaturalism ${ }^{10}$ Een seculiere kritiek richt zich op de analyse van deze culturele (en, met betrekking tot onze casus, religieuze) structuren en wil bovenal rekenschap afleggen van de impact van die structuren op de eigen manier van lezen, vertellen en, uiteindelijk, betekenis geven aan de wereld. In het geval van Don Wanderhope leidt zijn zoektocht in de roman uiteindelijk tot een dergelijk inzicht in zijn eigen verleden. Belangrijk daarbij is dat hij zijn Nederlandse gereformeerde erfenis accepteert als een onderdeel van zijn zelf en zelfbeeld terwijl hij niet terugkeert naar de religie of de geslotenheid die dit in zijn gemeenschap met hem meebracht.

The Blood of the Lamb, zo stellen wij, kan als uitgangspunt dienen voor een postseculiere benadering van de thematiek van religie in de moderne Nederlandse samenleving en de internationale impact daarvan. Dat kan volgens ons omdat de seculiere kritiek waartoe Edward Said ons aanspoort geen rigoureus afscheid van religie impliceert, maar juist een kritische 
analyse van de culturele en sociale patronen die religie in onze samenleving heeft genesteld. In dat opzicht sluit de observatie van Said uit Orientalism (uit 1978) uitstekend aan bij de recente debatten rondom postseculier denken. Het postseculiere dient niet begrepen te worden als een 'terugkeer' naar een religieuze samenleving of een herwaardering ervan. Integendeel, in de woorden van Hans Joas: 'Post-secular ... does not express a sudden increase in religiosity, after its epochal decrease, but rather a change in the mindset of those who, previously, felt justified in considering religions to be moribund. ${ }^{, 11}$ De analyse van religieuze structuren en hoe die doorwerken en nadreunen in onze samenleving, ook wanneer de publieke sfeer de facto geseculariseerd is, staat centraal in een postseculiere benadering. Dit is ook wat centraal staat in The Blood of the Lamb. De culturele en religieuze diaspora, de culturele en religieuze erfenis die Don Wanderhope van zijn ouders en vanuit zijn gesloten Nederlandse gemeenschap in Chicago meekreeg, is daarbij van eminent belang: de worsteling van Don Wanderhope met zijn eigen achtergrond maakt duidelijk dat de gewoontes en praktijken die door religie geïmplementeerd worden in de samenleving en in de psyche van het individu, elementen zijn die niet zomaar vervangen of afgeworpen kunnen worden. Wat dat betreft spreekt Dons achternaam - juist in relatie tot de Nederlandse taal waar Peter de Vries in de roman virtuoos mee speelt - boekdelen: Wanderhope, een veelzeggende naam in het Engels (hoop die steeds weer afdwaalt), maar die met het oog op het Nederlands een extra dimensie krijgt (wanhoop). Wanhoop en de vraag naar de onvermijdelijkheid van lijden (met of zonder geloof in God) is in onze lezing dan ook de centrale thematiek waarmee The Blood of the Lamb haar postseculiere reflectie verwoordt. De rituele structuur van de bekering, zoals die in het calvinistische milieu van Don Wanderhope opgeld doet, wordt door Peter de Vries als narratieve structuur gebruikt om deze reflectie kracht bij te zetten. Deze combinatie maakt de roman tot een werk dat tegenwoordig, in het licht van de recente debatten over de postseculiere maatschappij, als een postseculiere roman gelezen kan worden.

Om onze lezing van de roman uit te werken kijken we in de volgende twee secties naar drie narratieve momenten in de roman. Eerst behandelen we een geloofsbelijdenis die Don zelf schreef en die hij later weer tegenkomt via de cassetterecorder van zijn inmiddels overleden dochter. Aan de hand hiervan wordt duidelijk hoe de rite van de bekering in het leven van de seculiere Don Wanderhope een blijvende plaats krijgt. Vervolgens, in de sectie daarna, werken we dit verder uit door de openings- en slotscène van de roman met elkaar te vergelijken en te contrasteren. Daaruit wordt dui- 
delijk hoe de thematiek van de wanhoop Don uiteindelijk tot een postseculiere houding brengt. Die postseculiere houding, willen we argumenteren, is wat Wanderhope en daarmee ook The Blood of the Lamb niet enkel bijzonder maakt voor een roman uit 1961 maar ook als vergelijkingsmateriaal voor een comparatieve lezing in het licht van de Nederlandse religieuze erfenis.

\section{Leven en bekeren in postseculiere tijden}

In The Blood of the Lamb volgen we de geestelijke ontwikkeling van hoofdpersonage en verteller Don Wanderhope vanaf zijn jeugd in een orthodoxgereformeerd Nederlands immigrantengezin in de buitenwijken van Chicago tot journalist en schrijver in de buitenwijken van New York die net zijn enige dochter heeft verloren aan leukemie. Zoals hierboven al werd aangegeven, staat de ambigue relatie van Don met het christelijk geloof van zijn ouders, en de culturele achtergrond waar die van af stamt daarbij centraal. Deze tweeslachtige verbintenis tot zijn familiale achtergrond en geloof is echter ook onderhevig aan verandering. Het is juist deze verandering die voor ons van belang is in de analyse van de roman: de geestelijke metamorfose die de seculiere Don Wanderhope ondergaat, kan gelezen worden als een reflectie op de mogelijkheid en onmogelijkheid van secularisering in de Amerikaanse maatschappij vanaf het tweede kwart tot het midden van de twintigste eeuw, maar geeft ook aanleiding tot een reflectie op de postseculiere situatie die volgens denkers als Habermas en anderen onze eigen tijd kenmerkt, dat wil zeggen inmiddels algemeen verspreid is geraakt. $^{12}$

Waar de jonge Don Wanderhope nog een twijfelende toeschouwer is bij de debatten tussen zijn gelovige vader en zijn ongelovige, met de evolutieleer schermende oudere broer, vereenzelvigt hij zich in zijn adolescentie steeds meer met het standpunt van zijn (inmiddels overleden) broer. Langzaam maar zeker legt hij zijn geloof in God af. De wetenschap lijkt hem in eerste instantie het beste alternatief, en anders de filosofie wel. Wanderhope volgt het klassieke pad van de seculariserende, moderne mens. Maar uiteindelijk moet hij terugkomen op de zekerheid en het ersatz-geloof dat hij in de wetenschap hoopte te vinden. Wanneer Wanderhope op middelbare leeftijd gekomen is en voor het tijdschrift van zijn alma mater gevraagd wordt om een mission statement te schrijven waarin zijn levensopvatting naar voren komt, schrijft hij uiteindelijk het volgende: 
I believe that man must learn to live without those consolations called religious, which his own intelligence must by now have told him belong to the childhood of the race. Philosophy can really give us nothing permanent to believe either; it is too rich in answers, each cancelling out the rest. The quest for Meaning is foredoomed. Human life 'means' nothing. But that is not to say that it is not worth living. What does a Debussy Arabesque 'mean', or a rainbow or a rose? A man delights in all of these, knowing himself to be no more - a wisp of music and a haze of dreams dissolving against the sun. Man has only his own two feet to stand on, his own human trinity to see him through: Reason, Courage, and Grace. And the first plus the second equals the third. ${ }^{13}$

Vooraleer in te gaan op de ethische en religieuze strekking van Dons mission statement, willen we aandacht vragen voor de manier waarop deze passage in het narratief wordt ingezet. Dit blijkt immers allesbepalend voor de strekking van deze seculiere geloofsbelijdenis. Het opmerkelijke is dat deze passage tot tweemaal toe in haar volle lengte wordt geciteerd: een eerste keer wanneer Don het stuk instuurt voor het tijdschrift waarvoor hem een bijdrage werd gevraagd, en een tweede maal helemaal aan het eind van de roman na het overlijden van zijn dochter. Wanneer we de mission statement de tweede maal lezen, is het ook voor Don zelf een verrassing om dit oude stuk van eigen hand weer eens tegen te komen: hij was zijn eigen woorden vergeten en hoort ze nu met nieuwe oren. Enkele maanden na het overlijden van zijn dochter besluit Wanderhope om haar spullen door te nemen en te archiveren. Hij stuit daarbij op haar cassetterecorder. Uiteindelijk vindt hij de moed om de cassette die in het dek zit te beluisteren. De inhoud bestaat uit enkele kinderlijke opnames en kattebelletjes, maar krijgt extra gewicht door een boodschap die Carol heeft nagelaten aan haar vader. Carol zegt:

I want you to know that everything is alright Daddy. You've helped me a lot more than you can imagine. I was digging around in the cabinet part at the bottom of the bookshelves for something to read that you would like. I mean, not something from your favorite books of poetry and all, but something of your own. What did I come across but that magazine issue put out by your alma mater, with the piece in it about your philosophy of life. ${ }^{14}$

Het is op dit moment dat Carol, in haar eigen stem en als het ware over de dood heen, de woorden van haar vader uitspreekt. De eerste keer is het dus Don die de belijdenis voor zijn rekening neemt: hij is de auteur van het stuk. De tweede keer is de situatie aanzienlijk ambigue: Don is nog steeds 
de auteur van het stuk, maar het is Carol die het stuk serieus neemt en het met overtuiging uitspreekt. Dit zal voor Don een breekpunt blijken; een aanleiding om in het reine te komen met zijn eigen geestelijke formatie.

Het boeiende aan deze passage, helemaal aan het eind van de roman, is dat ze door middel van het medium van de cassetterecorder een conversatie met de doden mogelijk maakt, maar juist daarmee ook de mogelijkheid van religie in de weg zit. Met het beluisteren van de opname heeft Wanderhope in feite bereikt wat hij al die tijd miste in de religie: de mogelijkheid dat iets of iemand permanent zou kunnen zijn, teruggehaald kan worden uit de dood, weer werkelijk aanwezig kan zijn, bemind kan worden en een gesprekspartner kan zijn. Maar de manier waarop dit bereikt wordt, door middel van het materiële medium van de cassetterecorder, staat haaks op het uitgangspunt van zijn religieuze opvoeding: onthechting van de materiële werkelijkheid. In nogal emfatische bitterzoete bewoording omschrijft Don Wanderhope het als volgt: "The child on the brink of whose grave I tried to recover the faith lost on the edge of my brother's is the gatekeeper past whom I can now never get. ${ }^{15}$ Deze slotfase van het boek kan wat ons betreft gelezen worden als een religieuze bekering, maar dan ex negativo: door zijn eigen dochter door middel van een materieel medium (de cassetterecorder) over de dood heen met overtuiging zijn eigen seculiere geloofsbelijdenis te horen declameren, komt Don tot de realisering dat hij geen andere keuze heeft dan in het limbo van de wanhopende zoekende te verkeren. ${ }^{16}$

De mogelijkheid van verlossing na de dood wordt door middel van het samenspel van het toeval en de cassetterecorder op subtiel komische wijze onderuit gehaald, maar de situatie waarin Don zich bevindt heeft wel alle formele kenmerken van een bekeringsmoment. Samen met de wederopstanding van Christus, behoort de bekering van Paulus tot een van de belangrijkste onderdelen aan de hand waarvan het protestantisme zijn geloofspraktijk heeft vormgegeven. ${ }^{17}$ In de orthodoxe stroming van het protestantisme (waaronder bijvoorbeeld de 'bevindelijk gereformeerden' gerekend worden) bestaat het bekeringsproces steeds uit enkele stappen, waarbij het zogenaamde 'rock bottom' moment en het inzicht dat daaruit voortvloeit een centrale rol speelt. Het uitgangspunt hiervoor wordt in Paulus' achtste brief aan de Romeinen gevonden: 'Wie hij heeft uitverkoren, die heeft hij ook geroepen, die hij heeft geroepen, heeft hij ook gerechtvaardigd, en die hij gerechtvaardigd heeft, heeft hij ook geheiligd.' (Rom. 8: 30) De bekering vindt vervolgens als volgt plaats: 
De weg is gemarkeerd door 'kenmerken', dat wil zeggen, wie 'inwendig' geroepen is, weet dat hij uitverkoren is. Maar dat is niet genoeg. De uitverkorene moet bekeerd worden (door God) en zich bekeren (afzien van de zonde, de wereld mijden en zich wenden tot God).... Wie bekeerd is, krijgt kennis aan zijn zonde. Hij leert inzien dat hij een hater van God is, een verrader van de liefde Gods, een weerspannige, die onmachtig is ooit verandering in die staat aan te brengen. De kennis van die ellende is noodzakelijk. Wie zal immers beoordelen wat licht is, als hij het donker niet gekend heeft? De kennis, de eis van de wet van God, ontdekt de mens aan die zondestaat. ${ }^{18}$

In het leven van Don Wanderhope, zoals beschreven in The Blood of the Lamb, zien we hoe dit patroon zich voortdurend herhaalt; ook al is Don zelf niet meer gelovig, in zijn psychologische ontwikkeling maakt hij de verschillende stappen steeds opnieuw door. In zijn jonge jaren is hij vooral gericht op de wereld en aardse zaken. Hij wil vooruit in het leven, het liefst niet eindigen in een development. Hij twijfelt en stelt zijn hoop op de wetenschap. Die stelt hem teleur: ze kan hem niet helpen bij het redden van zijn dochter. Uiteindelijk bereikt Don een dieptepunt. Wat echter niet volgt, is de verlossing die daarmee gepaard kan gaan. Dat de religieuze omkering van Don de centrale thematiek van het boek vormt, mag duidelijk zijn. De angel van het verhaal, en de reden waarom dit boek volgens ons gelezen kan en moet worden als post-seculier, zit in de wijze waarop die bekering vanaf het begin van het boek in scène wordt gezet - en hopeloos faalt. De Vries doorloopt in feite alle passages die typerend zijn voor de religieuze omkering zoals die in de streng hervormde kerk wordt begrepen. $^{19}$

De openingsscène van The Blood of the Lamb blijkt in die zin een boeiend contrast te vormen met de slotscène, die we hieronder en in de volgende sectie van onze analyse nauwkeuriger bestuderen. De Vries begint zijn roman in medias res met een verhitte theologische discussie aan de keukentafel van huize Wanderhope. Vader en zoon voeren een discussie, daarbij geholpen door Hans, de broer van Ben die dominee is. Terwijl dominee Hans het rotsvaste geloof vertegenwoordigt, verdedigt ook vader Ben Wanderhope het geloof, al neemt hij wel een tussenpositie in. Onder de leden van zijn geloofsgemeenschap staat Ben Wanderhope te boek als de eeuwige twijfelaar, de piekeraar die nooit in overtuiging het geloof belijdt. De jonge Don voelt dit al goed aan, en beschrijft het gelaat van zijn vader als volgt: 'zijn gelaat gedroeg zich als van iemand die tegen zichzelf praat, wat hij feitelijk in niet geringe mate ook deed, zelfs tijdens het voeren van een gesprek. ${ }^{20}$, Het begin van het gesprek speelt zich af 
tussen de rechtlijnige Hans en de kritische, twijfelende Ben. Ben legt zijn betuttelende, hooghartige en humorloze broer Hans het zwijgen op met een reeks retorische vragen waartegen de laatste geen verweer heeft: 'Hoe sta ik ervoor, ik in de verdoemenis? Hoe sta ik ervoor met mijn twijfels aan, och ja, de hele bijbel, en niet alleen Genesis? Ik verklaar dat er geen hel is. Geloven jullie nu dat ik erin zal branden? Begrijpen jullie hoe ernstig dit is, en dat we maar beter weer aan de slag kunnen?'21

De jonge Don Wanderhope is niet enkel getuige van een theologische discussie tussen zijn vader en diens zwager, maar krijgt net als de lezer twee prototypes van het gelovige leven gepresenteerd: de twijfelende gelovige en de standvastige gelovige. De standvastigheid van Dons oom is voor zijn familie en omgeving een teken van zijn uitverkorenheid. Dit stelt de vader als twijfelaar in een nadelige positie; al is twijfel een volwaardig onderdeel van het bekeringsproces dat in het orthodoxe protestantisme cruciaal is, het is nog meerdere stappen verwijderd van een daadwerkelijke bekering. Dat hoeft niet te verwonderen, want Dons vader staat in de roman symbool voor het particuliere en seculiere dat ook de gelovige en gesloten gemeenschap van geëmigreerde protestantse Nederlanders omringt.

Dat het particuliere en het seculiere, veeleer dan rotsvaste geloofsovertuiging, een doorslaggevende rol speelt in de twijfelende vader van Don blijkt al uit zijn migratiegeschiedenis. Het was nooit het plan van Dons vader om naar Amerika te emigreren omwille van religieuze overtuigingen, zoals dat voor zo veel Nederlandse emigranten uit de tweede helft van de negentiende eeuw het geval was. The Blood of the Lamb opent dan ook met de volgende regels:

My father was not an immigrant in the usual sense of the term, not having emigrated from Holland, so to speak, on purpose. He sailed from Rotterdam to merely visit some Dutch relatives and friends who had settled in America, but on the way over suffered such ghastly seasickness that a return voyage was unthinkable. ${ }^{22}$

Dons vader zal uiteindelijk ook niet tot een bekering komen, wel valt hij steeds meer ten prooi aan twijfel, melancholie en hypochondrie. Uiteindelijk belandt hij in een psychiatrische kliniek die bestierd wordt door de kerk.

De gesprekssituatie tussen Dons vader en zijn oom Hans neemt een drastische wending wanneer de oudste zoon, Louie, zich erin mengt en de evolutietheorie propageert. Nu draait Dons vader bij en verdedigt hij 
vurig het geloof van zijn gemeenschap. De afvalligheid van Louie gaat als een schokgolf door het aanwezige gezelschap. De milde humor waarmee Peter de Vries dit beschrijft is overigens veelzeggend. In de vertaling:

Aan de keukentafel, waar inmiddels een kleine gemeente zat, stokte de adem. $\mathrm{Nu}$ de ketterijen samenpakken tot godslastering, verstijfden de mannen in hun zwarte pakken en vrouwen schudden hun hoofd. Hier waren onder één dak maar liefst twee kandidaten voor de geduchte afgescheidenen, en dat woord klonk voor wie zich hier schikte in het oudere absolutisme, even afschrikwekkend als 'laxeermiddel'. ${ }^{23}$

Dons oudere broer Louie, negentien en student aan de universiteit, vertegenwoordigt de opstandige zoon die zijn geloof heeft verruild voor de evolutietheorie. Louie krijgt een longontsteking. Nota bene op zijn sterfbed keert hij zich tegen het christelijke geloof en zelfs een laatste gebed vol gemeenplaatsen van de predikant bekeert de jongen niet. 'Wij weten dat dit kind van genade, deze zoon des Verbonds, in zijn jongelingsjaren heeft getwijfeld aan uw... Geef toch dat in dit uur... mocht het toch staan te gebeuren... vergeving zijner zonden in Jezus' naam, amen.' ${ }^{24}$

Don, die op dat moment zijn geloof nog aanhangt, is teleurgesteld in God, vraagt Hem om zijn broers herstel en voelt dat zijn gebed onbeantwoord blijft. Dit roept een zodanige ergernis in hem op dat hij een eerste stap weg van zijn geloof zet:

My sensation, rather than fear or piety, was a baffled and uncomprehending rage. That flesh with which I had lain in comradely embrace destroyable, on such short notice, by a whim known as divine? (...) Who wantonly scattered such charm, who broke such flesh like bread for his purposes? (...) Yet being unable to pray for Louie was loyalty to Louie, whose disciple I had early been. ${ }^{25}$

Dan beseft hij dat het uitblijven van respons eigenlijk een bevestiging is van wat zijn broer hem geleerd heeft: geloof is onzin. Omdat Louie belang hecht aan de gemoedsrust van zijn gelovige moeder, hakkelt hij op zijn sterfbed dat hij geen geloofstwijfel koestert. Opgelucht verlaten de kerkelijke omstanders en zijn moeder de slaapkamer, maar Don verkeert nog in zijn gezelschap en luistert als enige getuige naar het kruiswoord van Louie:

A single sigh of relief went through the room. Louie closed his eyes, and we were sure he was gone. Then, as I watched, I saw them open again and his gaze fix on me, and me alone. The old grin wreathed his lips once more as he said 
slyly, for just my benefit, "No doubts on my part." (...) No more need I go on thinking in anguished rage: "Why doesn't He pick on somebody his size?" "He" did not exist. So Louie had died saying. ${ }^{26}$

Louie, die reeds jong sterft, berust in de zekerheid van zijn ongeloof. Dat is Don echter niet gegeven. Voor hem is de vroege dood van zijn broer nog niet de basis voor een rationeel, seculier bestaan. In alle gebeurtenissen van Dons leven wisselen twijfel en zekerheid (zowel met betrekking tot geloof als atheïsme) elkaar af. Bovendien stelt deze roman zijn lezers de vraag of de zo trots gepresenteerde zekerheid van bepaalde individuen een teken van kracht of een teken van angst is. Immers, wie zich verzekerd weet in het bezit te zijn van een alomtegenwoordige waarheid, heeft totaal niet de behoefte zijn bevestiging buiten zichzelf om te zoeken. Wie vreest dat het niet helemaal klopt, hecht wellicht meer waarde aan bijval. Twijfel en onzekerheid zijn de ware geloofskracht: 'You mean you're not sure? Why, man, that's great! For the rest of us, who like to hug that little doubt we so desperately need today - what faith was to folk of another time - the ray of hope. Oh, how grateful we are for that uncertainty! Our salvation almost. $^{27}$ Zijn twijfel heeft hij behouden.

\section{3 'Sta me toe te wanhopen': postseculiere geloofsstructuren}

De reden dat het volgens ons zin heeft te spreken van de postseculiere mentaliteit van Don Wanderhope, en juist daarmee ook de reden dat de roman een rol kan vervullen in het debat over postsecularisering, is dat hij zich, verrassend genoeg misschien, niet ontwikkelt tot een door de wol geverfde atheïst. Don Wanderhope, zo stelt onder meer Willem Jan Otten, volhardt in iets uiterst tegenstrijdigs: terwijl hij als personage van de ene existentiële crisis in de andere tuimelt, roept hij als verteller die terugkijkt op deze momenten God ter verantwoording. ${ }^{28}$ Dit zien we niet alleen gebeuren wanneer hij zijn negentienjarige broer verliest, of enige tijd later wanneer hij een vriendin verliest aan tuberculose of wanneer zijn moeder sterft, maar bovenal aan het eind van de roman, als zijn dochter sterft aan bloedkanker. Hij schippert tussen haat en liefde jegens de God die er al of niet is en hij vraagt uiteindelijk toestemming om te wanhopen: 'I ask, my Lord, permission to despair. ${ }^{29}$ In die zin kunnen we stellen dat Don Wanderhope de postseculiere tijdgeest representeert: de publieke ruimte mag dan geseculariseerd zijn, de psychische ingesteldheid en de daarmee over- 
eenkomende gedragspatronen van Don zijn gevormd door zijn religieuze opvoeding. Zijn persoonlijkheid kan hij niet meer losmaken van die opvoeding, en daar heeft hij aan het eind van de roman vrede mee.

Om de hypothese dat Don zich uiteindelijk vereenzelvigt met deze postseculiere houding nauwkeuriger te onderbouwen loont het de moeite om een van de laatste scènes uit de roman nader te bekijken, een scène die zich afspeelt in het oncologisch ziekenhuis waar zijn dochter behandeld wordt voor leukemie. Daar vindt Don Wanderhope een lotgenoot: Stein. Ook het kind van Stein ligt op sterven. De confrontatie met Stein is een tweede rite van bekering waaraan we in dit artikel aandacht willen schenken, om zo de postseculiere implicaties van The Blood of the Lamb aan te tonen. De halsstarrigheid die Stein vertoont tegen het geloof blijkt voort te komen uit diepe teleurstelling. Don vindt in zijn postseculiere ingesteldheid geloof en ongeloof even verdedigbaar, maar Stein niet:

'Believers believe what they want to believe. I would like to believe it, too, but deny that an honest man can. Unbelief is to that extent less suspect than faith.' (...) Here a vibration of anger escaped Stein that was not put into words, but that I felt had given me a flash of illumination into his spirit - something that might even be held to confirm the theory of my friend to which I had been needled into giving audible expression. Stein resented the sedative power of religion, or rather the repose available to those blissfully ignorant that the medicament was a fictitious blank. In this exile from peace of mind to which his reason doomed him, he was like an insomniac driven to awaken sleepers from dreams illegitimately won by going around shouting, "Don't you realize it was a placebo!" Thus it seemed to me that what you were up against in Stein was not logic rampant, but frustrated faith. He could not forgive God for not existing. ${ }^{30}$

Stein waarschuwt voor de bedwelmende werking die geloof kan uitoefenen op de realiteitszin van de mens. Maar die waarschuwing gaat gepaard met een passie die voor Don alleen maar begrepen kan worden als een zelfverkozen ballingschap: waar iedereen slaapt en droomt is Stein een slaapwandelaar, zijn zelfverkozen 'exil' zorgt ervoor dat hij nog steeds actief betrokken is bij de gemeenschap van gelovigen maar er zelf geen onderdeel meer van kan zijn. In dat opzicht is Stein voor Don het prototype van de atheïst, waarvan het waardensysteem zich steeds op directe wijze verhoudt tot dat van de theïst. Althans, het zet zich er fel tegen af.

Het probleem van dit standpunt van Stein, volgens Don, is dat het tot een vorm van wanhoop leidt die oneigenlijk is, die slechts dient om een 
nog grotere wanhoop op afstand te houden. Stein spreekt echter zijn verbazing uit over mensen die geloven in een God die willens en wetens zoveel chaos toelaat. Stom toeval heeft nog meer liefde in zich, vindt hij: 'Blind and meaningless chance seems to me so much more congenial - or at least less horrible. Prove to me that there is a God and I will really begin to despair.' (208) The Blood of the Lamb kan in deze context gelezen worden als een onderzoek naar de mogelijkheid van werkelijke, totale wanhoop: Don, die cultureel gezien nooit helemaal in staat is om zijn geloof van zich af te schudden, ervaart ten gevolge daarvan een werkelijke, totale wanhoop - werkelijk en totaal, juist omdat zowel de mogelijkheid van het bestaan van God als het niet bestaan van God tot wanhoop moeten leiden voor hem. Maar in tegenstelling tot Stein, die doelbewust voor het laatste pad kiest (het niet-bestaan van God) heeft Don daarmee wel de wanhoop onder ogen gezien. Ook hier zien we dus weer het cultureel Christelijke patroon van de bekering terug: alleen wie de werkelijke wanhoop, de werkelijke rock bottom bereikt, kan een kans maken op bekering en verlossing. Ironisch genoeg bereikt Don deze rock bottom door te twijfelen, dat wil zeggen: door te erkennen dat hij niet weet of God bestaat of niet, en dat beide opties voor hem gelijk zijn, even wanhopig. De grondslag van waaruit het bekeringsproces hier wordt geschetst is dus, opmerkelijk genoeg, postseculier.

De thematiek van de wanhoop die in The Blood of the Lamb centraal staat concentreert zich, wederom vanuit een Christelijk cultureel patroon, op de vraag waarom mensen moeten lijden. Tot Dons frustratie is dat lijden vaak de ware drijfveer achter de geloofsovertuiging van zijn familie en kennissen. Enerzijds belooft het geloof verlossing van het lijden, doordat het zin geeft aan het leven en een perspectief op verlossing biedt, maar anderzijds dragen alle gelovige personages waarmee hij in aanraking komt de opvatting uit dat men in het leven moet lijden. Het dogma hierachter luidt, in de bondige bewoording van Don, in de vertaling als volgt: 'Hoeveel je gelooft, vertelt hoeveel je lijdt. ${ }^{31}$ Don deelt zijn verbazing en frustratie over de nauwe samenhang van geloof en lijden met Stein. Maar in tegenstelling tot Stein, die door zijn rancuneuze verzet tegen het geloof in feite net zozeer aan het lijden ten prooi valt, weigert Don het lijden als leidmotief van het leven te beschouwen. Wel ziet hij de pijn en erkent hij dat woede en wanhoop gerechtvaardigd zijn, mits mensen het recht hebben deze te ventileren: 
We live this life by a kind of conspiracy of grace: the common assumption, or pretense, that human existence is 'good' or 'matters' or has 'meaning', a glaze of charm or humor by which we conceal from one another and perhaps even ourselves the suspicion that it does not, and our conviction in times of trouble that it is overpriced - something to be endured rather than enjoyed. Nowhere does this function more than in precisely such a slice of hell as a Children's Pavilion, where the basic truths would seem to mock any state of mind other than rage and despair. Rage and despair are indeed carried about in the heart, but privately, to be let out on special occasions, like savage dogs for exercise, occasions in solitude when God is cursed, birds stoned from the trees or the pillow hammered in darkness. ${ }^{32}$

Kwaad is Don zeker. Hij kan het niet verkroppen dat hij blootgesteld wordt aan de schier onverdraaglijke pijn zijn kind te moeten begraven, terwijl gelovige mensen gedachteloos en plichtmatig zulke zware termen als lijden' en 'pijn' in hun mond durven te nemen. Zij hebben geen flauw benul wat echt verderf is, dat de hel niet bestaat. Of jawel, hij bestaat en hij is gewoon op aarde, bijvoorbeeld op de afdeling kinderkanker. De dood van Christus is geen verzachting voor zijn bestaan dat zodanig bol staat van ontberingen, dat zelfs Job hem niet benijden kan. Otten bespeurt zowaar een latent aanwezig Jobmotief in The Blood of the Lamb, omdat Don kwijtraakt wie hem het liefst is: Carol. ${ }^{33}$ God zou toch degene moeten zijn die als geen ander Zijn mededogen en ontferming kan tonen of haar gewoon kan redden. Maar Hij is er niet:

Dead-drunk and cold-sober, he wandered out to the garden in the cool of the evening, awaiting the coming of the Lord. No such advent taking place, he shook his fist at the sky and cried, 'If you won't save her from pain, at least let me keep her from fear! ${ }^{34}$

Zijn dochter en de andere jonge patiënten zijn weerloos, kunnen niets doen tegen de verwoestende gezwellen, en voor God is hun dood net zo nietszeggend als die van een muis. ${ }^{35}$ De geschiedenis van de kwetsbare Louie herhaalt zich hier voor Don Wanderhope; zijn dochter sterft. Peter de Vries verwoordt deze uitgeschreven Pieta als volgt:

Then I touched the stigmata one by one: the prints of the needles, the wound in the breast that had for so many months now scarcely ever closed. I bent to kiss the cheeks, the breasts that would now never be fulfilled, that no youth would ever touch. "Oh, my lamb." 36 
Carol is de lijdensfiguur en belichaamt het symbool van de christelijke Onschuld: het lam, wiens bloed nota bene vergiftigd is door medicijnen en carcinomen. Ze sterft en haar vader betraant haar stigmata.

\section{Conclusie: van seculiere kritiek naar postseculiere roman}

In de analyse wordt duidelijk dat Peter de Vries niet zozeer een synthese zoekt tussen het religieuze en het seculiere, als wel het onderlinge gesteggel tussen de twee concepten als geheel psychologiseert. Blijkbaar kunnen de twee tendensen zonder elkaar niet bestaan en is secularisering weliswaar een continuüm, maar niet noodzakelijk een lineair ontwikkelingsproces. Om diezelfde reden heeft de religiewetenschapper Asad religie en secularisering beschreven als een spreekwoordelijke Siamese tweeling. ${ }^{37}$ Hiermee bedoelt hij dat de twee hun bestaansrecht ontlenen aan elkaars aanwezigheid, evenwel zonder een universele waarheidsclaim te kunnen maken. De idee dat men via hermeneutiek tot de meest adequate lezing van religieuze geschriften komt, verwerpt hij. Een maatschappij kiest haar eigen meest wenselijke lezing en representatie van godsdienstige overtuigingen, ${ }^{38}$ zelfs wanneer een deel hiervan wordt ontkend of verloochend. Asads opvatting is belangrijk voor de roman, omdat de vitaliteit van het geloof versterkt wordt door een zekere rancune jegens datzelfde geloof. De aversie vindt haar voedingsbodem in de seculiere wereld en diens secularisatieverhalen, die geen oplossing bieden aan Don Wanderhope. ${ }^{39}$

De religieuze heropleving die de afgelopen decennia een rol lijkt te spelen, is voor Habermas de reden om te spreken van een postseculiere wending in onze maatschappijen. ${ }^{40}$ Ook Otten wijst op deze heropleving in zijn bespreking van The Blood of the Lamb. ${ }^{41}$ In The Blood of the Lamb komen we de complexe situatie waarin ons dit brengt in feite al tegen. Don Wanderhope heeft weliswaar meerdere malen in zijn leven gebroken met het christelijke geloof, maar het keert telkens weer terug als een boemerang. Als volgeling van zijn broer Louie lijkt hij zich aanvankelijk te verzoenen met een sec, wetenschappelijk wereldbeeld waarin de mens een nietige, onbeduidende schakel is. 'After his death, Louie remained as much as ever a model to me, or even more, being now idealized in my mind. ${ }^{42}$ Maar in de loop van de roman ziet hij zichzelf steeds weer terugkeren tot de ideeën, instituties en waarden die hem vanuit zijn geloof zijn meegegeven. The Blood of the Lamb is een zelfonderzoek: de door religie getekende seculiere Don Wanderhope ondervindt wat het betekent om 
ook na het afwerpen van religie toch met de religieuze waarden verder te moeten leven.

Jürgen Habermas noemt een aantal voorwaarden voor een religie om haar houdbaarheid te consolideren, waarvan de belangrijkste is dat de moderne wetenschap ook voor de gelovige als uitgangspunt moet dienen bijvoorbeeld in medische kwesties. Het geloof kan daarnaast blijven bestaan en waarde of zin geven aan de wereld en het leven. Deze voorwaarde zien we gerealiseerd in The Blood of the Lamb. ${ }^{43}$ De wetenschap wordt inderdaad beschouwd als de bezitter van seculiere kennis en het religieuze bewustzijn van Don Wanderhope ontdoet zich van verabsoluteringen (hetzij in atheïstische, hetzij in calvinistische richting). De Vries verwoordt het treffend: 'Airing the absolutes is no longer permitted in polite society. ${ }^{44} \mathrm{We}$ zouden dus kunnen stellen dat het religieuze maar ook geseculariseerde bewustzijn, vertegenwoordigd door Don Wanderhope, onderhevig is geworden aan flexibilisering: vanuit een in essentie gelovige, zelfs streng calvinistische achtergrond, is er voor Don ruimte voor discussie over geloofswaarheden. Dit blijkt duidelijk wanneer hij in het gezelschap verkeert van Stein. Deze versoepeling heeft echter wel een definitieve breuk met het calvinisme tot gevolg:

In my present need Stein might seem the last company I ought to seek. Yet in another sense he was precisely what I wanted at my side, the Devil's advocate off whom to bounce my speculations, the rock against which to hurl my yearnings and my thoughts, to test and prove them truly, an office that mealymouthed piety could not have performed. He was the goalkeeper past whom I must get my puck. ${ }^{45}$

Onenigheid is niet hinderlijk en een persoon met religieus bewustzijn moet zich herhaaldelijk ter herinnering roepen dat hij in de minderheid verkeert. De voorrang moet gegeven worden aan rechtvaardigheid en niet aan geloofsovertuigingen, sterker nog: een waarlijk reflexieve, flexibele religie maakt deze ruimhartigheid tot norm volgens menig postseculier theoreticus. ${ }^{46}$ Daar kan geen enkele vrome gemeenplaats tegenop en daarom breekt Don met het calvinisme, niet met spiritualiteit. Don is zich bewust van zijn eigen historische en culturele bepaaldheid en dat maakt hem in The Blood of the Lamb tot een postseculier personage. Hij zal altijd meer geseculariseerd willen zijn, dan hij echt is. En dat deert hem niet. 


\section{Noten}

1. Swieringa (2003a); Stob (1995).

2. Swieringa (2003a), 10.

3. Cf. Apter (2005), 59.

4. Schoone-Jongen (2008), 69; Bratt (1984), 8.

5. Swieringa (2003b).

6. Swieringa (2003b).

7. Van der Hoek (2014).

8. Schoone-Jongen (2008), 69; Bratt (1984), 8.

9. Otten (2008), 222.

10. Said (1978), 120-121.

11. Hans Joas geciteerd in Sullivan en De Vries (2006), 2.

12. Habermas (2001); Habermas (2003).

13. De Vries (1961), 241-242.

14. De Vries (1961), 241.

15. De Vries (1961), 244.

16. Cf. Hauerwas (1990), 25.

17. Bruce (1977), 75 .

18. Van der Meiden (1968), 41.

19. Van der Meiden (1968).

20. De Vries (1961), 9.

21. De Vries (1961), 16.

22. De Vries (1961), 3.

23. De Vries (1961), 10.

24. De Vries (1961), 27-28.

25. De Vries (1961), 24-25.

26. De Vries (1961), 41.

27. De Vries (1961), 212.

28. Cf. Otten (2008).

29. De Vries (1961), 225.

30. De Vries (1961), 190.

31. De Vries (1961), 25.

32. De Vries (1961), 215.

33. Otten (2008); Coulehan (2003); Frank (2004).

34. De Vries (1961), 204.

35. De Vries (1961), 225.

36. De Vries (1961), 234.

37. Asad (1993); Mozumder (2911), 51-51.

38. Asad (1993); Mozumder (2011), $5^{2}$.

39. Paul (2013), 18.

40. Habermas (2008), 20.

41. Otten (2008).

42. De Vries (1961), 31.

43. Habermas (2003), 115.

44. De Vries (1961), 215.

45. De Vries (1961), 209.

46. Habermas (2008); Rummens (2007), 10. 


\section{Bibliografie}

Apter, E., The Translation Zone. A New Comparative Literature, Princeton University Press, Princeton, 2005 .

Asad, T., Genealogies of Religion: Discipline and Reasons of Power of Reason in Christianity and Islam, Johns Hopkins University Press, Baltimore, 1993.

Bratt, J.D., Dutch Calvinism in America. A History of a Conservative Subculture, W.B. Eerdmans Publishing, Grand Rapids, 1984.

Coulehan, J., 'The Blood of the Lamb', in: Literature, Arts, and Medicine Database, New York University, New York, 2003. URL: http://litmed.med.nyu.edu/Annotation?action=view\&annid=12120

Frank, J., 'A critic at large. Riches of Embarrassment', in: The New Yorker, 24-05-2004, URL: http:// www.newyorker.com/archive/2004/05/24/040524fa_fact_frank?currentPage=all

Habermas, J., Glauben und Wissen, Suhrkamp, Frankfurt am Main, 2001.

Habermas, J., The Future of Human Nature, Polity Press, Cambridge, 2003.

Habermas, J., 'Notes on Post-Secular Society', in: New Perspectives Quarterly 24, 2008, 4, 17-29.

Hoek, S. van der, Langs de nullijn. De twee kanten van Nederland, Arbeiderspers, Amsterdam, 2014.

Mozumder, M.G.N., Interrogating Post-Secularism. Jürgen Habermas, Charles Taylor, and Talal Asad, proefschrift geschreven aan de Universiteit van Pittsburgh, Pittsburgh, 2011.

Otten, W.-J., 'Nawoord' in: Peter de Vries, Het Lam, Brandaan, Rotterdam, 2008.

Paul, H.J., Ziektegeschiedenissen. De discursieve macht van secularisatieverhalen. Oratie aan de Rijksuniversiteit Groningen, Groningen, 2013.

Rummens, S., 'Hoe seculier is de postseculiere samenleving? Jürgen Habermas over religie in de publieke sfeer', in: Ethiek \& Maatschappij 8, 2007, 4, 7-23.

Said, E., Orientalism, Vintage Books, New York, 1978.

Schoone-Jongen, T., The Dutch American Identity. Staging Memory and Ethnicity in Community Celebrations, Cambria Press, Amherst, 2008.

Stob, H., Summoning up Remembrance, W.B. Eerdmans Publishing, Grand Rapids, 1995.

Sullivan, E.A. \& Vries, H. de, Political Theologies. Public Religions in a Postsecular World, Fordham University Press, New York, 2008.

Swieringa, R., Dutch Chicago. A History of the Hollanders of the Hollanders in the Windy City, W.B. Eerdmans Publishing, Grand Rapids, 2003a.

Swieringa, R., 'The Urban Experience in Dutch Immigrant History', lezing voor de Biennial Conference of the Association for the Advancement of Dutch American Studies (AADAS), Trinity Christian College, 6 juni 2003, URL: http://www.swierenga.com/Urban_lecture.html (2003b).

Vries, P. de, The Blood of the Lamb, Little, Brown and Company, Boston, 1961.

\section{Over de auteurs}

Daan Lameijer werkt als docent Nederlands op het christelijk lyceum Zandvliet in Den Haag.

E-mail: daanlameijer@hotmail.com

Bram Ieven is universitair docent moderne Nederlandse letterkunde aan de Universiteit Leiden.

E-mail: b.k.ieven@hum.leidenuniv.nl 


\section{Recent verschenen bij uitgeverij AUP}

De nieuwe serie Language \& Culture in History gaat in op de rol van buitenlandse talen bij het ontstaan van het taalkundige en culturele erfgoed van Europa. Er wordt onderzoek gedaan op zowel individueel, regionaal, nationaal en internationaal niveau. De eerste drie titels in de reeks zijn recent verschenen!
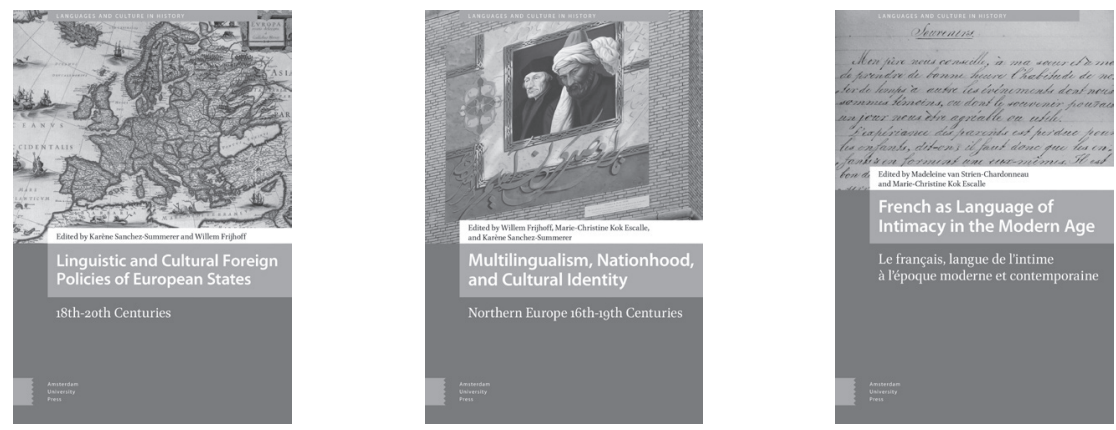

Linguistic and Cultural Foreign Policies of European States. 18th-20th Centuries, Sanchez-Summerer en Frijhoff (red.) | hardback | ISBN 978946298060 0 | € 89.00 Multilingualism, Nationhood, and Cultural Identity. Northern Europe, 16th-19th Centuries, Frijhoff, Kok Escalle en Sanchez-Summerer (red.) | hardback | ISBN 9789462980617 | € 79.00 French as Language of Intimacy in the Modern Age, Van Strien-Chardonneau en Kok Escalle (red.) | hardback | ISBN 9789462980594 | € 89.00

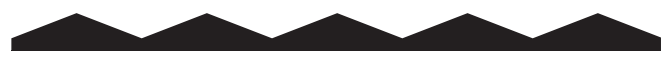

Soms ligt het op het puntje van je tong. Vaak weet je dat een bepaalde uitdrukking bestaat, maar kun je er even niet opkomen.

Met zoveel woorden van Rik Schutz en Ludo Permentier wijst de weg naar manieren waarop je in het Nederlands iets krachtig en/of beeldend kunt zeggen. Een geweldig bladerboek voor alle taalliefhebbers en onmisbaar voor tekstschrijvers en vertalers.

Met zoveel woorden, Rik Schutz en Ludo Permentier | paperback | € 29,95 | ISBN 9789462981805 | e-ISBN: 9789048531561

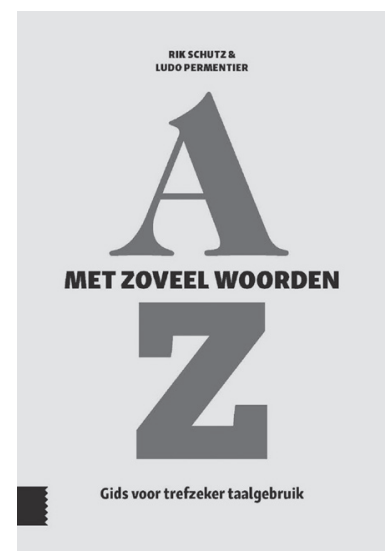

